\title{
Correction to: Charismatic Leadership and Work Team Innovative Behavior: the Role of Team Task Interdependence and Team Potency
}

\author{
Pascale M. Le Blanc ${ }^{1}$ (D) $\cdot$ Vicente González-Romá ${ }^{2} \cdot$ Haijiang Wang ${ }^{1,3}$
}

Published online: 7 January 2020

(C) The Author(s) 2020

\section{Correction to: J Bus Psychol https://doi.org/10.1007/s10869-019-09663-6}

The original version of this article unfortunately contained a mistake. The captions of Figures. 1 and 2 were exchanged. The correct captions are shown below:

Fig. 1 The moderated indirect model. Note: Control variables (team size, team tenure) are not presented for clarity. Standardized coefficients are presented. $* p<.05 ; * * p<.001$. The number of teams is 133

Fig. 2 The moderation effect of time 1 interdependence (IT1) on the relationship between time 1 charismatic leadership (CLT1) and time 2 team potency

The original article has been corrected.

Open Access This article is licensed under a Creative Commons Attribution 4.0 International License, which permits use, sharing, adaptation, distribution and reproduction in any medium or format, as long as you give appropriate credit to the original author(s) and the source, provide a link to the Creative Commons licence, and indicate if changes were made. The images or other third party material in this article are included in the article's Creative Commons licence, unless indicated otherwise in a credit line to the material. If material is not included in the article's Creative Commons licence and your intended use is not permitted by statutory regulation or exceeds the permitted use, you will need to obtain permission directly from the copyright holder. To view a copy of this licence, visit http://creativecommons.org/licenses/by/4.0/.

Publisher's Note Springer Nature remains neutral with regard to jurisdictional claims in published maps and institutional affiliations.

The online version of the original article can be found at https://doi.org/ 10.1007/s10869-019-09663-6

Pascale M. Le Blanc

P.M.Le.Blanc@tue.nl

1 Human Performance Management Group, Eindhoven University of Technology, P.O. Box 513, 5600, MB Eindhoven, The Netherlands

2 IDOCAL, University of Valencia, Valencia, Spain

3 School of Management, Huazhong University of Science and Technology, Wuhan, China 